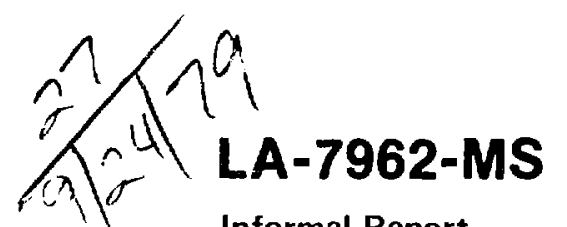

Informal Report

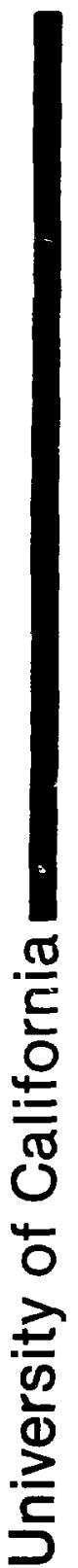

A Preliminary Evaluation of the

Radioactive Waste Isolation Potential of the Alluvium-Filled Valleys of the Great Basin 
LA-7962-MS

Informal Report

UC.70

Issued: August 1979

\title{
A Preliminary Evaluation of the \\ Radioactive Waste Isolation Potential of the Alluvium-Filled Valleys of the Great Basin
}

\author{
J. R. Smyth \\ B. M. Crowe \\ P. M. Halleck \\ A. W. Reed*
}

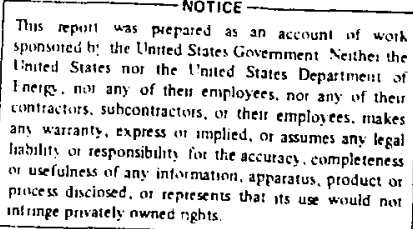

*Sandia Laboratories, Organization 5511, Albuquerque, NM 87185.

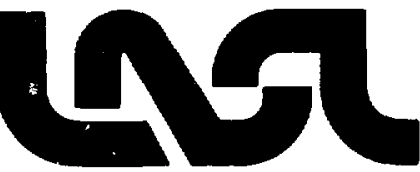




\section{A PRELIMINARY EVALUATION OF THE RADIOACTIVE WASTE ISOLATION POTENTIAL OF THE ALLUUVIUM-FILLED VALLEYS OF THE GREAT BASIN}

\section{by}

J. R. Smyth, B. M. Crowe, P. M. Halleck, and A. W. Reed

\section{ABSTRACT}

The occurrences, geologic features, hydrology, and thermal, mechanical, and mineralogical properties of the alluvium-filled valleys are compared with those of other media within the Great Basin. Computer modeling of heat conduction indicates that heat generated by the radioactive waste can be dissipated through the alluvium in a manner that will not threaten the integrity of the repository, al though waste emplacement densities will be lower than for other media available. This investigation has not revealed any failure mechanism by which one can rule out alluvium as a primary waste isolation medium. However, the alluvium appears to rank behind one or more other possible media in al1 properties examined except, perhaps, in sorption properties. It is therefore recommended that alluvium be considered as a secondary isolation medium unless primary sites in other rock types in the Great Basin are eliminated from consideration on grounds other than those considered here.

\section{INTRODUCTION}

The concept of deep geologic storage of radioactive wastes has been under study since 1957 . Several types of rock units have been investigated to evalwate their suitability as waste repository media. Most notably, salt has received first priority as a potential medium, while some investigations have considered granite, argillite, basalt, and tuff. There is some agreement concerning the necessary (but not necessarily sufficient) characteristics required for storage and isolation of radioactive wastes. These characteristics have been recently outlined by Brunton and McClain (1977). Briefly, the criteria include: 
1. Occurrence. The rock units must be of sufficient thickness and extent to effectively isolate radioactive wastes for periods of at least $10^{5}$ years. The medium should have little economic value in order to minimize projected resource conflicts and possible repository violation by future mineral exploration.

2. Tectonic Setting. The rock units should occur in a region of relative geologic stability to minimize the risk of earthquake damage during the required pericd of retrievability. Additionally the medium should be relatively undisturbed by recent tectonic deformation and volcanic activity.

3. Hydrology. Ground water transport is considered the primary vehicle for movement of radionuclides out of a repository. The rock units of the site and surroundings must have suitable hydrologic properties to minimize ground water access to the site. Ground water transport is considered the primary vehicle for movement of radionuclides out of a repository. Ground water migration rates should be low, flow path distances to discharge areas should be long, and discharge areas shouid be distant from population centers. Additionally, it may prove advantageous to avoid eventual ground water discharge to the ocean.

4. Thermal Properties. If high or intermediate level wastes are to be stored, the thermal diffusivity of the rock medium will largely determine the amount of waste which can be stored per unit area. Heat generated by the waste must be dissipated through the medium in such a manner as not to threaten the short-term retrievability or long-term integrity of the repository.

5. Mechanical Properties. Fracture strength and fracture density of rock units will largely determine mining costs. Instantaneous and time-dependent stress-strain responses must be consistent with short-term retrievability and long-term integrity of the repusitory.

6. Mineralogical Properties. The minerals of the repository host rock must not undergo low temperature phase transitions, which would threaten the long-term integrity of the repository. In addition, the mineralogy of the geologic medium should be such that migration of ground water borne radionuclides is minimized by sorption effects, assuming eventual ground water access to the repository.

None of the rock types under consideration optimally satisfies all required criteria. Choice of a suitable repository medium will require a judicious selection of rock types and hydrologic environments which most adequately meet 
the criteria considered to be most important to long-term containment of radioactive wastes. In a companion study, the authors have considered the waste isolation potential of silicic pyroclastic rocks. It is the object of the current study to evaluate the waste isolation potential of dry alluvial valleys of the Great Basin. The principal object shall be evaluation of alluvium as a primary emplacement medium for high level waste or spent commercial reactor fuel. However, other geologic rock types of the Great Basin are under active consideration for radioactive waste isolation and alluvium lies along most paths to the biosphere from these other media. It is therefore anticipated that this report will also serve as a preliminary evaluation of the secondary waste isolation potential of alluvium. The report is a review of known occurrences and physical properties of the alluvium and preliminary modeling of heat dissipation from hypothetical waste repositories.

\section{GENERAL GEOLOGIC FEATURES}

Aliuvium, according to the American Genlogical Institute Glossary of Geology, is "a general term for all detritial deposits resulting from the operations of modern rivers, thus including the sediments laid down in river beds, flood plains, lakes, fans at the foot of mountain slopes, and estuaries." Within the Great Basin area of the Basin-Range province (including the Nevada Test Site!, broad, low-standing valleys separating major mountain ranges are partly filled with moderate $(>100 \mathrm{~m})$ t.) substantial thicknesses $(>300 \mathrm{~m})$ of clastic sedimentary rocks. These basin deposits, or valley fill, are commonly referred to by the generzlized term alluvium. By this usage, alluvium refers to a variety of rock types including alluvial fan, fluvial (river deposits). fanglomerate (indurated alluvial-fan deposits), lake bed, debris flow, and minor deolian or wind-blown deposits. Volumetrically, most sedimentary rock within the alluvial basins occurs as coalesced alluvial fans or bajadas (Blissenbach, 1954). An alluvial fan is a deposit "whose surface forms a segment of a cone that radiates downslope from the point where the stream leaves the mountain" (Bu11, 1972, p. 63).

The geology of alluvial fans, particularly within the arid southwestern United States, has been described by numerous authors (for example, Blackwelder, 1928, 1931; Blissenbach, 1954; Denny, 1965; and see Bul1, 1972 for a modern summary). Major cross-sectional features of a fan are shown on Fig. la; Fig. 1b 
is a plan view showing the distribution of fan facies and the predominant transport processes on fan surfaces.

The characteristics of sedimentary deposits of a fan are determined by the major transportational and depositional processes that operate on the fan surfaces. Consequently, alluvial fan deposits have greatly varying particle size characteristics (Bu11, 197?). They range in size from boulder and sand to
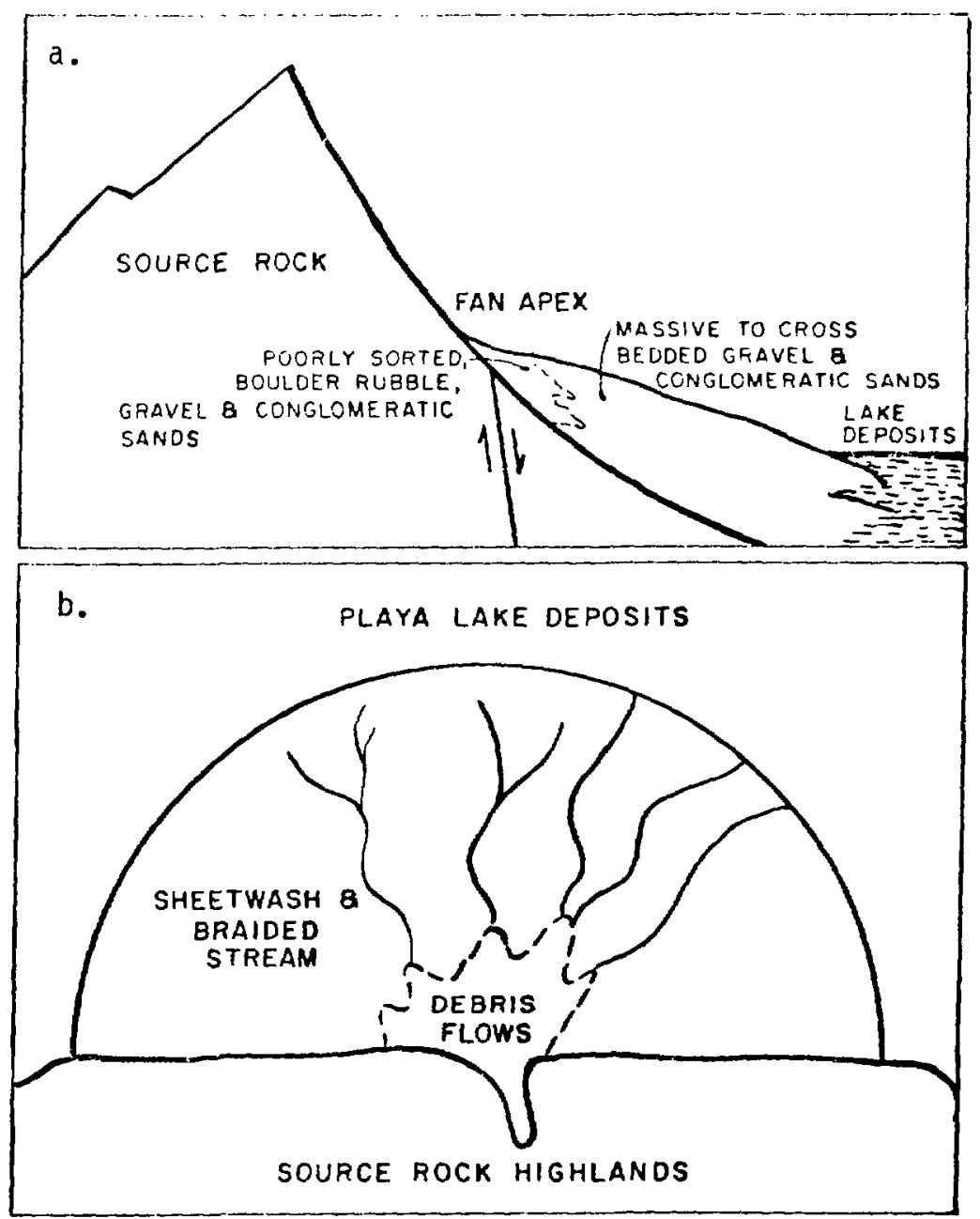

Fig. 1

Schematic diagrams of alluvial fan deposits showing hypothetical facies distributions; $a$. cross section, b. plan view. 
fine-grained silt and clay. In general there is a systematic decrease in particle grain size of fan deposits from the apex to the distal base of a fan (Blissenbach, 1954; Lustig, 1965; Hooke, 1967). Individual facies or rock types of fans are highly lenticular; they characteristically are deposited as sheets along the fan surface. The location of active depositional zones migrates during fan accumulation, consequently fan deposits interfinger complexly both vertically and laterally through a fan cross-section.

Debris-flow deposits, generally formed near the apex of a fan surface, tend to be very coarse (boulder to sand size) and poorly sorted (BTissenbach, 1954). They generally are lobate in form with sharp margins, and because of their high density and viscosity (non-Newtonian flow), are capable of transporting very large particles (Bu11, 1975). Sheetwash deposits consist of gravel to sand-and silt-sized particles. They characteristically are well sorted and massive to laminated or cross-bedded. Stream or fluvial deposits form as local channel fill and are generally more coarse grained and less well sorted than sheetwash deposits.

The composition of alluvial-fan deposits is determined by several features.

- The composition of the source rock.

- The position and migration of the fan apex during successive depositional cycles.

- The degree of downslope overlap or coalescence of separate fars (commonly with differing source rocks).

- Nature anr degree of weathering of the source rock (in the arid Great Basin, the weathering cycle is predominantly mechanical and source rocks are modified primarily by mechanical fragmentation).

- Secondary alterations following deposition, especially the formation and infiltration of clays by ground-water action (Walker et al., 1978).

Newly formed alluvial fan deposits are generally unconsolidated. Through time the rocks become indurated or hardened to form a coherent rock. There are several major processes of induration. Alluvial deposits with a significant proportion of matrix material (predominantly clays) will become indurated by compaction of the matrix. A second process of induration of alluvial deposits is precipitation of matrix cement in pore spaces most commonly by circulating ground water. Common cementation minerals include zeolites, authigenic feldspar, cristobalite, calcite, and quartz. 


\section{OCCURRENCES}

The Nevada Test Site (NTS) contains several major alluvial basins including Yucca Flat, Frenchman Flat and Jackass Flat (Fig. 2). Alluvial deposits are up to $575 \mathrm{~m}$ thick beneath Yucca Flat, $370 \mathrm{~m}$ thick beneath Frenchman Flat, and $320 \mathrm{~m}$ thick in Jackass Flat (Winograd and Thordarson, 1975). The characteristics of these basins and other alluvial valleys within the Great Basin, are typified by Yucca Flat. Yucca Flat is a topographically closed, intermontane basin bounded by rugged mountains consisting of Precambrian and Paleozoic sedimentary rocks, Mesozoic plutonic rocks, and Cenozoic volcanic rocks (Fig. 2). Drill hole data has shown that alluvial deposits within the flat overlie an irregular surface carved primarily on the Cenozoic volcanic rocks (Fernald arid others, 1968).

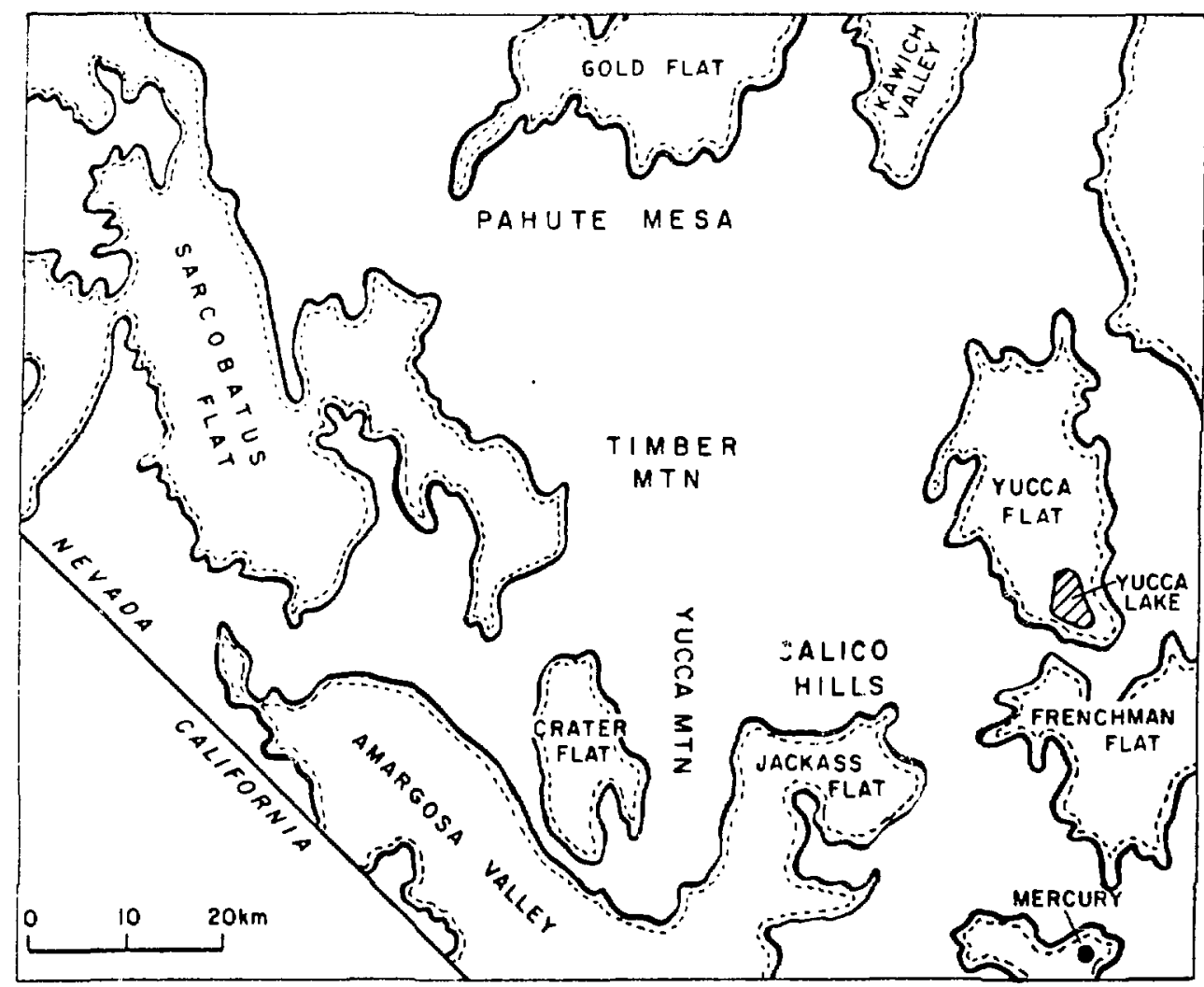

Fig. 2

Map of a portion of the Great Basin in southern Nevada showing the distribution of alluvial basins (flats). The eastern half of the map area lies largely within the Nevada Test Site. 
Surficial deposits comprise coalesced alluvial fans that extend down basin from bordering bearock highlands. The southern end of the Basin is occupied by a playa lake (Yucca Lake, Fig. 2). Fernald and others (1968) identified four types of fan deposits among the surficial deposits of Yucca Flat. These range from stream deposits of braided streams draining the fan surface (sandstone and conglomerate) to coarse rubble deposits emplaced as debris flows at the apex of fan segments. The clastic constituents of valley fill in the NTS has been described from numerous test wells. Major alluvial types include silt, sand, gravel (unconsolidated), and minor clay-rich, lake deposits. Major clast types in the gravels include tuff (welded, unwelded, zeolitized and non-zeolitized), quartzite, chert, limestone, dolomite, and argilitite--the major lithologies of the bordering mountain ranges. Descriptions of the alluvial types and proportions of rock types have been given in various NTS reports. Price and Thordarson (1961), for example, have divided alluvial gravel into suburits based upon the main lithologic components. Representative types include walded-tuff gravel, quartzite gravel, etc. Matrix materials of the alluvial deposits generally control the degree of induration. These materials include calcite (secondary cement), clays, zeolites, cristobolite, and authigenic feldspars. The content of matrix materials is controlled in large part by source terrane. For example, ailuvial sands and gravels derived from volcanic scurce rocis generaliy have a high content of tuff fragments (tuffaceous alluvium) as well as zeolites and clays. These rocks, because of their large percentage of iuffaceous components, have excellent sorptive properties with respect to radioactive cations (Hoffman and others, 1977).

IV. HYDROLOGIC PROPERTIES

The hydrologic properties of alluvium are difficult to generalize because of the extreme variability in grain size and depositional characteristics of the deposits. Porosity and permeability of alluvium are strongly dependent upon the shape, packing, size distribution (notably matrix-size constituents) and cementation of particles. These features, particulariy particle packing and size characteristics, are largely controlled by depositional node. Thus the depositional patterns of alluvial fans can significantly affect hydrologic characteristics (Davis and others, 1966i (Table 1). For example, apex areas of fans are composed predominantly of poorly sorted debris-flow deposits with relatively low average permeability. Sheetwash and braided stream deposits, 
TABLE I

POROSITY AND PERMEABILITY OF SELECTEL ALLUVIAL DEPOSITS

\begin{tabular}{|c|c|c|}
\hline Dominant Size & $\begin{array}{c}\text { Permeabilitiy, } \\
\text { Darcys } \\
\end{array}$ & $\begin{array}{c}\text { orosity } \\
(\%)\end{array}$ \\
\hline Fine Sand & 26.4 & 51.1 \\
\hline Fine Sand & 25.3 & 51.5 \\
\hline Fine Sand & 16.5 & 47.0 \\
\hline Fine Sand & 13.2 & 45.7 \\
\hline Fine Sand & 5.5 & 52.2 \\
\hline Coarse Sand & 189.0 & 33.3 \\
\hline Gravel & 1130 & 25.1 \\
\hline Gravel & 43500 & 38.0 \\
\hline
\end{tabular}

Davis \& Dewiest (1966) p. 375

particularly the iatter, have higher permeabilities. Distal parts of fans, where the deposits interfinger with playa silts have lower permeabilities and tend to be poor aquifers.

Local aquifers are common in alluvial deposits at the NTS. These waterbearing deposits, termed the valley-fill aquifer, are used for water supply in Frenchman Flat, western Emigrant Valley and the Amargosa Desert (Winograd and Thordarson, 1975). However, the aquifers are of limited extent because of the great depth of the water table in the NTS region, very low surface recharge rates, and facies variability. Consequently for this region, only a small fraction of the total thickness of alluvium is saturated.

Hydrologic characteristics of valley-fill aquifers are known only from scattered test wells, primarily in Yucca and Frenchman Flats. Porosity values for alluvial samples in Yucca Flat range from 16 to 42 percent and averaged 31 percent (Price and Thordarson, 1961; Thordarson and others, 1962). Interstitial permeabilities of valley-fill aquifer range from on the order of $2.0 \times 10^{-3}$ to $2.5 \times 10^{-2} \mathrm{~cm} / \mathrm{sec}$. Hoffman and others (1977) report average hydraulic conductivities of alluvium from test well holes (estimated from grain-size 
analyses) to be about $4 \mathrm{~m} /$ day. This compares with productivity (test we 11 RN: $1-2,5 B$ and $5 \mathrm{C}$ ) of 1.5 to as $10 \mathrm{w}$ as $0.2 \mathrm{~m} /$ day. They note the presence of alluvial aquitards formed by argillaceous (siity) seciments. These rocks, based on measurements from 30 cores, have values for hydraulic conductivity ranging from $10^{-9}$ to $2 \times 10^{-2} \mathrm{~m} /$ day with a median value of abcut $2.5 \times 10^{-6} \mathrm{~m} /$ day (Hoffman and others, 1977, p. 16).

\section{MECHANICAL PROPERTIES}

Mechanical properties of Great Basin alluvium may be subdivided into those properties which principally affect short-term (<100 yr) retrievability and those which principally affect long-term (>100 yr) integrity. Because of the extrene variability of mineralogy and lithology, the assessment of both groups of mechanical properties will be difficult, and site-specific. However a preliminary estimate of the range of ohysical property values will permit an estimate of mining costs required to insure retrievability.

Because ground water transport of dissolved radionuclides is assumed to be the principal hazard to long-term containment, the mechanical properties which most strongly affect long-term containment are those which bear on the hydrology of the riedium as previously discussed. The mechanical properties which principally affect short-term mineability and retrievability are fracture strength, fracture density, creeo (squeezing ground), and compressibility. Failure envelope (shear strength vs, confining pressure) data have been taken for samples from sites in northern Yucca Flat and northern Frenchman Flat (Bonner et a1., Heard and Stephans). In iddition to samples tested with the in situ water content, several of the res stituted samples from che Yucca Flat site were tested at varying water contents ranging from saturated (approximately 20 wt \%) to dry. The results of these tests are shown in Fig. 3. Data from Frenchman Flat samples are also plotied in the figure and are seen to be consistent with Yucca Fiat data. It is clear that increasing water content weakens the rocks severely. This is probably due to a decrease in friction between particles in the rock and to weakened induration by solution. For comparison, data from an 83\%-saturated bedded tuff from area 12 are also shown (Stephans et al.).

Pressure-volume data for these rocks show very high initial compressibilities due to compaction. Effective initiai compressibiities may be as high as $5 \mathrm{GPa}^{-1}$, decreasing rapidly with pressure to values of $0.1 \mathrm{GPa}^{-1}$ at 0.2 


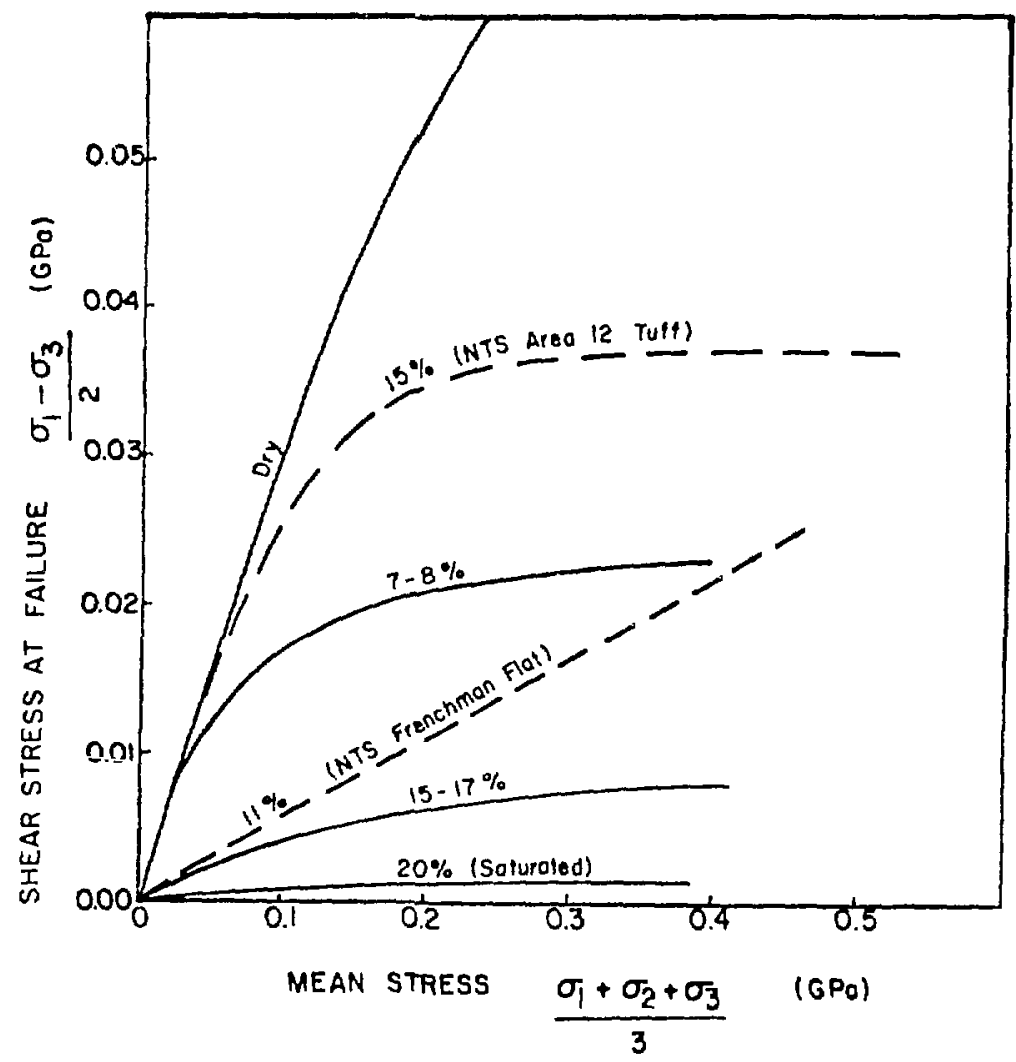

Fig. 3

Comparison of failure envelopes for wet and dry alluvium samples and for partially saturated tuff. Solid lines are data for reconstituted alluviums from Yucca Flat showing wt \% water content. Straight dashed line is for a Frenchman's Flat alluvium with in situ water content of $11 \%$ wt $\%$. Curved dashed line is for a tuff from Area $1 \frac{1}{\text { with }} 15 \mathrm{wt} \%$ water. All porosities are in the range of 20 to $25 \%$ volume.

GPa confining pressure. Compressibilities measured above this pressure are fairly consistent from sample to sample, but at lower pressures a great deal of variation is seen depending on initial density, water content and degree of induration. Insufficient data are available to quantitatively evaluate these relations.

An estimate of mining costs may be made from experience in a single test experiment in Area 2 of Yucca Flat (Hertig; Flangas). In this experiment a $2 \times$ $3 \mathrm{~m}\left(6^{\circ} \times 10^{\prime}\right)$ drift was tunneled for several hundred feet in the alluvium. No special procedures were required. Wooden sets were used rather than steel and no shotcrete or rockbolts were required. The material was said to have behaved 
essentially like tuff, with mining costs'equivalent to that material. Although no data are available on the water content or degree of induration in this material, it is assumed that this alluvium was relatively well indurated.

The construction costs of shafts and tunnels in granite, argillite and tuff have been estimated by Yanev and Owen (1978) (Table II). The higher cost of uriderground construction in argillite relative to granite and tuff is due principally to anticipated presence of "squeezing ground" which would require steel sots. The extreme variability of physical properties of alluvium mears that squeezing ground will likely be encountered in some area of an underground construction particularly in less indurated material. In such areas mining costs may be expected to be equal to or greater than those in argillite.

\section{SORPTIVE PROPERTIES}

In consideration of a terminal repository for radioactive wastes in any geologic formation within the Great Basin, the sorptive prorerties of the alluvium are of primary importance because the alluvium can serve as a natural sorption barrier between the wastes and the biosphere. It may be assumed that a principal vehicle for radionuclide migration from any repository will be aqueous solution in ground water. Transport rates can be minimized by formulating an insoluble waste form, by selecting a site with very low ground water migration rates (or a site above the water table), and by selecting a site with geologic

\section{TABLE II}

\section{ESTIMATED UNDERGROUND CONSTRUCTION COSTS*}

$(\$ / \mathrm{m})$ in various media

\begin{tabular}{|c|c|c|c|c|}
\hline & $\begin{array}{l}\text { Tunne1s } \\
(5.5 \mathrm{~m})^{2} \\
\end{array}$ & $(7.9 m)^{2}$ & $\begin{array}{l}\text { Shafts } \\
(5.0 \mathrm{~m})^{2} \\
\end{array}$ & $(3.4 \mathrm{~m})^{2 *}$ \\
\hline Granite & 2390 & 11100 & 8830 & 5890 \\
\hline Tuff & 2520 & 11400 & 8830 & 6210 \\
\hline Argillite & 4580 & 16000 & 11500 & 6870 \\
\hline
\end{tabular}

* Data from Yanev and Owen converted to metric units. **Turned cross-sectional area. 
material of high sorption coefficients for the hazardous nuclides. The tuffaceous alluvium of the Great Basin commonly contains significant anounts of clay and zeolite minerals, which have relatively large specific surface r.reas and large sorption ratios for fission-product radionuclides.

There is almost no published information on the natural aqueous solution chemistry of fission-broduct elements or the sorption properties of spacific minerals for these elements. However, there are recent studies of radionuclide migration rates from underground nuclear tests below the water table in alluvium (Hoffman and others, 1977 and Wolfsberg, 1978). Laboratory sorption ratio measurements on tuffaceous alluvium from Frenchman Flat yielded retention factors of greater than $200 \mathrm{foi}$ antimony, strontium, and iodine; greater tian 202 ? for ruthenium, niobium, barium, cesium, and cobalt; and greater than 29 log for yttrium: cerium, and europium. Further information on the solution chemistry of these elements and the dotinides under natural pty conditions :rould be reruireat before establishment of a repository in geologic formations within the great Basin: However, the results of the above studies indicate that the alluriun can serve as effective sorptive barrier to radionuclide migration.

\section{THERMAL PROPERTIES}

If intermediate or high level wastes are to be stored, heat generated b; waste must be dissipated in such a manner as to not threaten the integrit: of the repository. In order to insure that this can take place, various heat jicsipation mechanisms nust be understood to predict the time-temberature-sace relationship around the repository, and mineralogical reactions in the rost rock must be understood to establish an upper temperaturs limii for the repositor; medium. Additionally mechanical response to themal stress nust be understood in order to insure retrievability.

As pointed out by smyth and others (1979) neat issipation by sinrie conduction may be regarded as a lower bound of heat transfer. Compiex heat transfer mechanisms involving the movement of fluids nay become important if significant amounts of water are present in the host rock. The thermal diffusivity (a function of density, heat capacity, and thermal conductivity; of the alluvium is expected to be quite viriable and will depend upon compaction, clast lithology, induration, and water saturation. However, there are limits to the variability and since conduction is the lower bounding heat transfer 
mechanism, useful results can be obtained from calculations based upon average and extreme values.

Dry volcanic soils containing significant amounts of pumice can be very good thermal insulators with typical conductivities ranging down to approximately 0.2 watts per meter-Kelvin (W/mK) (Clark, 1966). However, with water saturation thermal conductivity may increase by an order of magnitude. Typical values abtained in the laboratory on recompacted near-surface soils from Jackass Flat ranged from 0.5 to $0.8 \mathrm{~W} / \mathrm{mK}$ and should be similar to those for indurated tuffaceous alluvium.

This gives a range of values, which can be used for modeling heat dissipation from a waste repository in alluvium. We can use $0.2 \mathrm{~W} / \mathrm{mk}$ as the lower limit of thermal conductivity with some confidence. We know that such conductivities cannot persist for more than a few meters in depth, because they would result in unreasonable thermal gradients $(>300 \mathrm{~K} / \mathrm{km})$ given the regional natural heat flow in southern lievada $(r, 2 \mathrm{HFU})$. We expect a mean value of about $0.5 \mathrm{~W} / \mathrm{mK}$ for unsaturated unconsolidated alluvium and between 1.0 and $1.2 \mathrm{~W} / \mathrm{mK}$ for indurated unsaturated alluvium and have used these values for thermal conduction computer models.

For purposes of modeling, it is useful to have an estimate of the upper tenperature limit for the host rock. This is somewhat difficult to set for a heterogeneous material such as alluvium, but temperature will likely be limited either by excessive water vapor (steam) pressure buildup or by thermal breakdown of minerais. Much alluvium has rather high gas permeabilities, so it is unlikely that steam pressure accumulations will occur. We assume therefore that cemperature is limited by thermal breakdown of hydrous minerals, which could impair the retrievability of the wastes. With increasing temperature, clay minerals will progressively dehydrate, losing loosely bound interlayer water above $100^{\circ} \mathrm{C}$ and losing bound water in the range of $300^{\circ} \mathrm{C}$ to $500^{\circ} \mathrm{C}$. Zeolites behave similarly, losing absorbed water above $100^{\circ} \mathrm{C}$. Analcite begins to break down to anhydrous phases at about $200^{\circ} \mathrm{C}$, while other zeolite minerals may retain their structural water and mechanical strength to as high as $700^{\circ} \mathrm{C}$. For purposes of heat conduction modeling, we have chosen $250^{\circ} \mathrm{C}$ as an upper temperature limit for unsaturated alluvium. A site specific in situ heat test would be required to more closely define this limit. 


\section{THERMAL MODELING}

As discussed previously, heat loss by conduction is assumed to be the lower bounding heat loss mechanism of a repository in alluvium. That is, any other heat luss (e.g. fluid transport), if significant, will operate in addition to simple conduction. Heat loss by conduction can be modeled using existing thermal conduction codes. Since excessive temperatures are believed to be a likely failure mechanism of a repository in alluvium due to low thermal conductivities relative to other media, it was deemed useful to evaluate the maximum thermal loads consistent with a maximum temperature of $200^{\circ}$ to $250^{\circ} \mathrm{C}$.

Modeling of heat loss by conduction was undertaken using several different model geometries, differing computer codes and various hypothetical waste forms. The first model was set up for a preliminary evaluation of the variables involved. The model used the two-dinensional finite element heat flow code TSAAS. The model assumed ten-year-old high level waste emplaced as one $3.4 \mathrm{k} / \mathrm{d}$ canister per ten-meter cube $\left(1000 \mathrm{~m}^{3}\right),\left(3.4 \mathrm{~W} / \mathrm{m}^{3}\right)$ and assumed that the heat source was evenly distribited over the emplacement horizor. The model gecmetry is illustrated in Fig. 4 along with thermal property assumptions. The heat generation decay was simplified to a double exponential closed form, one with an initial $3.4 \mathrm{~kW} /$ canister and 30 year half-life and the other with an initial 5 W/canister and 5000 year half life. Two cases were run, one with a high conductivity alluvium $(1.0 \mathrm{~W} / \mathrm{mK})$ and the other with a low conductivity ailuviuin $(0.2 \mathrm{~W} / \mathrm{mK})$. The results yielded a maximum temperature of $225^{\circ} \mathrm{C}$ for the high conductivity alluvium. This indicated a marginally acceptable result for the first case and an unacceptable result for the second and a need to further refine the effect of the various variables, particularly thermal conductivity, waste type, emplacement depth and emplacement density. in addition, the near-field effects of various waste forms will need to be addressed.

The second model evaluated the overall heat loads possible for 100 and 300 meter burial depths. This model was one-dimensional and employed the finite difference heat flow code CINDA. The model geometry assumed the heat source was a single planar element, corresponding to the entire repository, at a depth of either 100 or $300 \mathrm{~m}$. The waste forms hypothesized were high level waste at 10 years and at 100 years after fission assuming initial $\mathrm{UO}_{2}$ fuel oniy ino plutonium recycling) and spent fuel at 10 years and at 100 years after fission also assuming initial $\mathrm{UO}_{2}$ fuel only. Thermal power decay functions used were those of Lincoln and others (1978). 


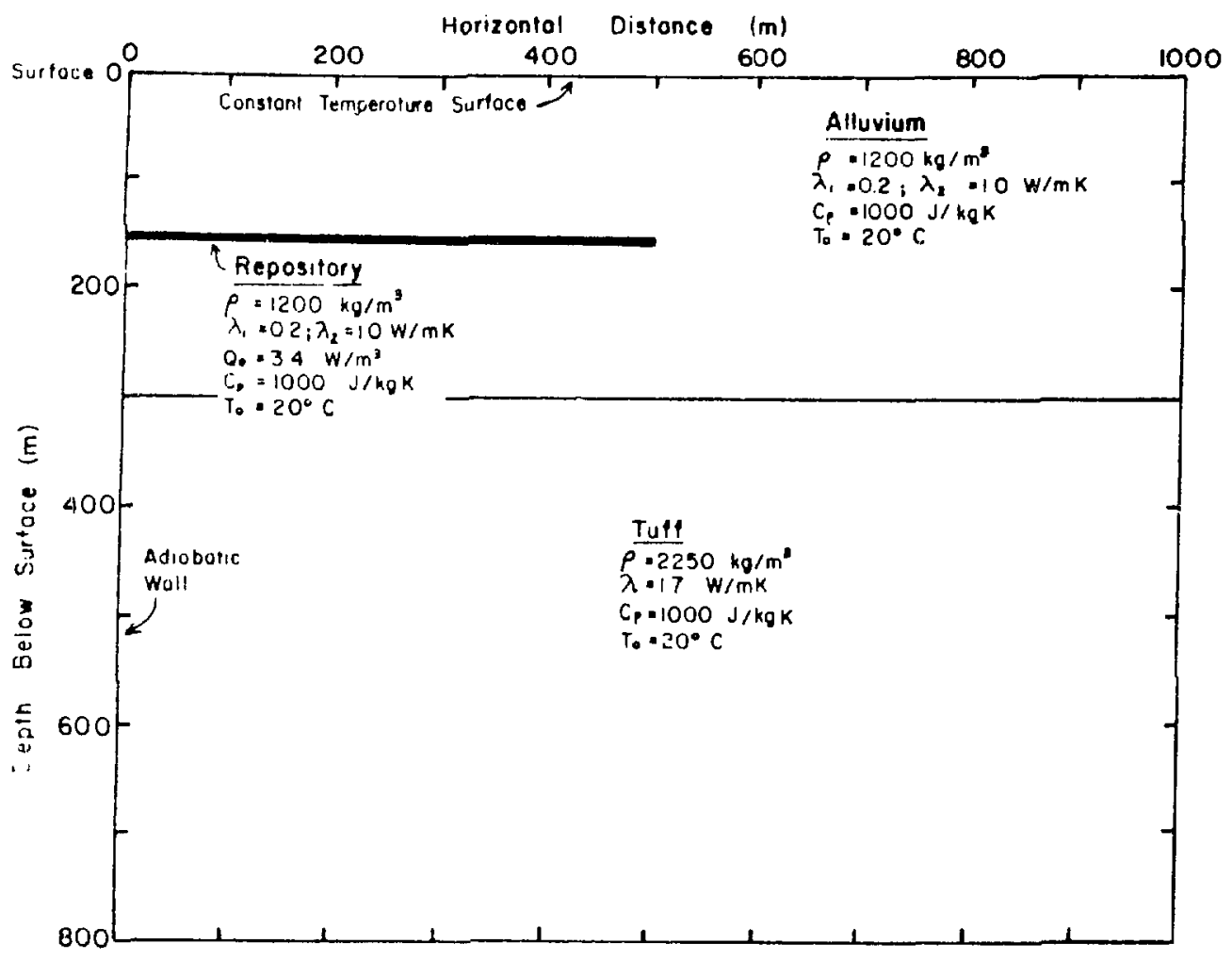

Fig. 4

Thermal Model I. Cross section of a hypothetical waste repository in alluvium located at a depth of $160 \mathrm{~m}$. The density $(p)$, thermal conductivity $(\lambda)$, heat capacity $(C p)$, and initial temperature (To) of the various units are given on the diagram.

The thermal conductivities used were $0.2,0.5$, and $1.2 \mathrm{~W} / \mathrm{mK}$. Assuming a regional heat flow of 2.0 heat flow units $\left(=2 \times 10^{-6} \mathrm{cal} / \mathrm{cm}^{2} \mathrm{sec}\right)(=0.084$ $\mathrm{W} / \mathrm{m}^{2}$ ) thermal gradients of $0.42,0.17$, and $0.070 \mathrm{k} / \mathrm{m}$ were calculated respectively for alluvium at each of the above conductivities. From these gradients, initial temperature distributions were calculated. Conductivities, thermal gradients, initial temperature distributions and allowable temperature rises (assuming the maximum temperature is $250^{\circ} \mathrm{C}$ ) are given in Table III. The four different waste forms (spent fuel and high level waste each aged 10 and 100 years), three different types of alluvium (Table III) and two burial depths (100 and $300 \mathrm{~m}$ ) gave a matrix of 24 cases to be tested using the one-dimensional heat-flow model. For each case an initial emplacement density was assumed, and 
the peak temperature versus time and the temperature distribution at several times were calculated. The model assumed a constant heat capacity and thermal conductivity with temperature; therefore the temperature rise should vary linearly with emplacement density. A plot of maximum temperature rise versus time for one case is given in Fig. b. Using the maximum allowable temnerature rises (Table III) the maximum al lowable emplacement densities were calculated by linear scaling and are presented in Table IV.

This model assumes a distributed heat source, that is, the waste is evenly mixed over the repository horizon. The object is primarily to see how much land area would be required to isolste a significant portion of the nation's commercial nuclear wastes. If the U.S. consumes a cumulative total of 500000 metric tons of $U$ fuel (MTU) by the year 2 oon (higher than most estimates) this results in areas ranging from 2.7 to $165 \mathrm{~km}^{2}$, which would be required to dissipate the generated heat. This model has not addressed the thermal effects near the canister which may well prove limiting.

\section{TABLE III}

THERMAL PROPERTIES, INITIAL TEMPERATURE DISTRIBUTIONS, AND MAXIMUM ALLOWABLE TEMPERATURE RISES FOR THREE HYPOTHETICAL ALLUVIUM CONDUCTIVITIES

$\begin{array}{lccc} & \# 1 & \# 2 & \# 3 \\ \text { Thermal Conductivity }(\mathrm{W} / \mathrm{m} \cdot \mathrm{K}) & 0.20 & 0.50 & 1.20 \\ \text { Density }\left(\mathrm{kg} / \mathrm{m}^{3}\right) & 1200 & 1700 & 1700 \\ \text { Heat Capacity }(\mathrm{J} /(\mathrm{kg} \cdot \mathrm{K})) & 1000 & 1000 & 1000 \\ \text { Initial Surface Temperature }\left({ }^{\circ} \mathrm{C}\right) & 15 & 15 & 15 \\ \text { Initial Temperature at } 100 \mathrm{~m}\left({ }^{\circ} \mathrm{C}\right) & 57^{\circ} & 32^{\circ} & 22^{\circ} \\ \begin{array}{l}\text { Initial Temperature at } 300 \mathrm{~m}\left({ }^{\circ} \mathrm{C}\right) \\ \text { Maximum Allowable Temperature }\end{array} & 141 & 65 & 36 \\ \text { Rise } 100 \mathrm{~m}(\mathrm{~K}) & 193 & & 218 \\ \begin{array}{l}\text { Maximum Allowable Temperature } \\ \text { Rise } 300 \mathrm{~m}(\mathrm{~K})\end{array} & 109 & 185 & 214\end{array}$


TABLE IV

RESLLIS OF ONE-DIMEHSIOMAL HEAT FLOW CALCULATION USING FINITE DIFFERENCE HEAT FLOW CODE CIIDA MAXIMUM EMPLACEMENT OENSITIES CONSISTENT WITH A HAXIMUM TEMPERATURE OF $250^{\circ} \mathrm{C}$ ARE SIVEN FOR EACH CASE

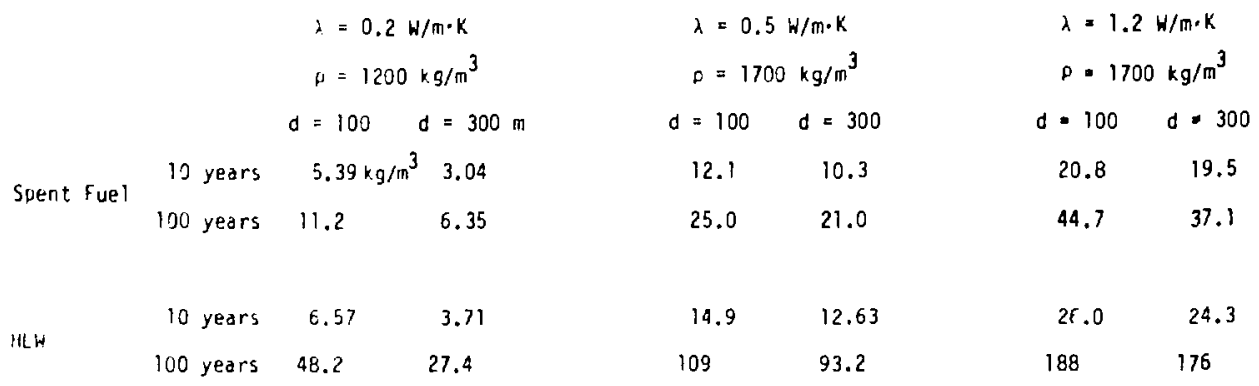

Expressed as $\mathrm{kg}$ of original $u$ fuel per $\mathrm{m}^{2}$ of repository. To convert to metrlc tons of fuel per acre multiply by 4.047 .

TABLE $V$

MAXIMUM TEMPERATURE RISES AND TIME OF MAXIMUM TEMPERATURE FOR TWO OIMENSIONAL HEAT FLOH FROM HYPOTHETICAL WASTE CANISTERS

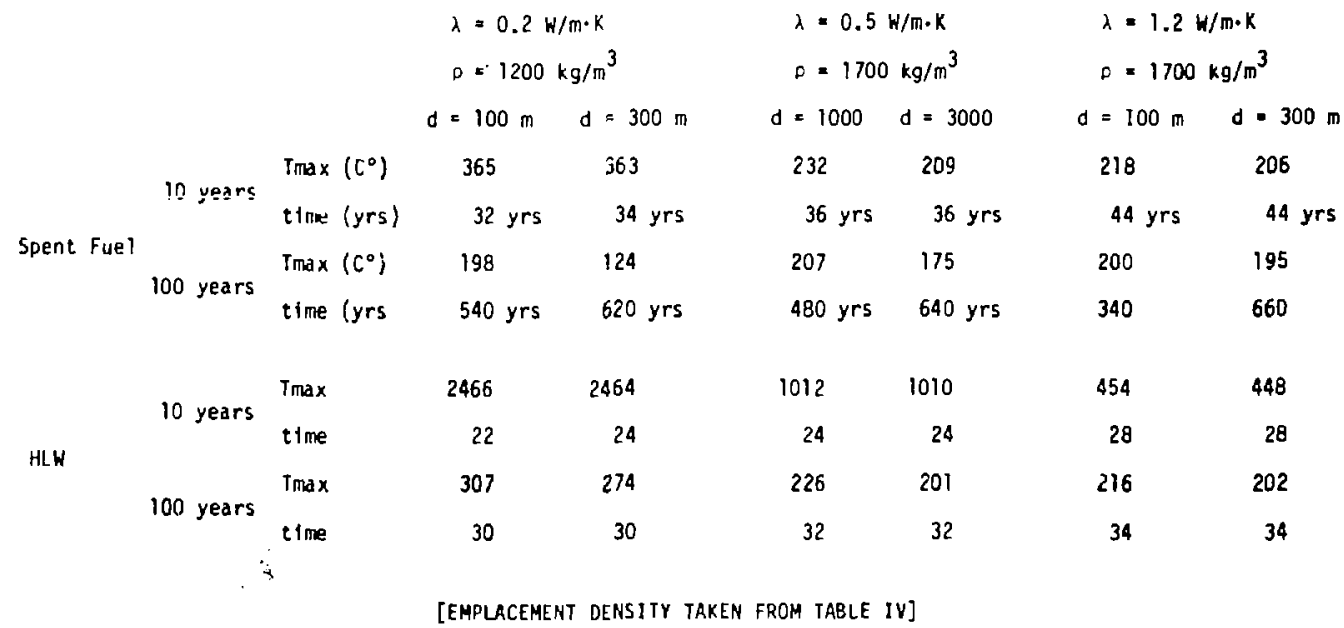




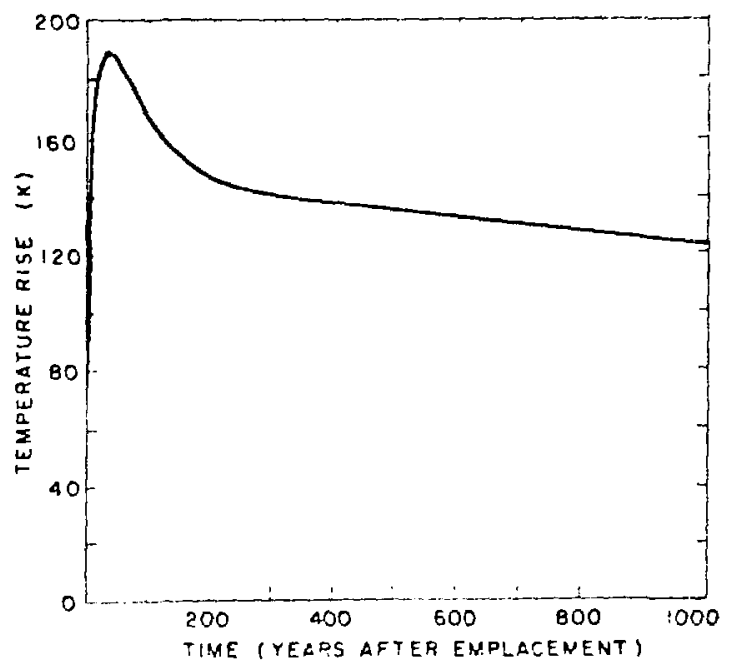

Fig. 5

Thermal Model II. A plot of temperature versus time at the point of maximum temperature (the repository horizon) calculated using the one-dimensional heat flow model. The case illustrated is for ten-year-old spent fuel in a medium of $0.5 \mathrm{~W} / \mathrm{mK}$ conductivity with emplacement density of $10.3 \mathrm{~kg} \mathrm{U} / \mathrm{m}^{2}$.

Using the same waste types and medium properties, near-field effects were investigated using a two-dimensional heat flow model and the same finite difference code (CINDA). Model geometry is illustrated in Fig. 6 along with the temperature distrisution at the time of maximum temperature for one case. The package assumptions were those of a borosilicate glass high-level waste container such as designed for use in a salt repository (corresponds to 3.0 MTU with $99.5 \% \mathrm{U}$ and $\mathrm{Pu}$ removed) and a pressurized water reactor (PWR) fuel assembiy for the spent fuel (0.46 MTU) both with a burn-up of 33000 , MW-days per MTU. Heat generation was assumed to be evenly distributed over each waste package.

The calculation resulted in a temperature distribution about each waste package similar to that illustrated in Fig. 6. The temperature maximum was located at the center top of the canister and this maximum temperature followed a build-up and decay curve with time similar to that illustrated in Fig. 5 . The maximum temperature and the time of the peak temperature are given in Table $V$ for each of the 24 cases investigated in the first model.

Several significant trends appear in these results. First, it appears that the very low conductivity alluvium would result in unacceptable temperature rises for each waste form modeled except 100-year-old spent fuel. Second it 


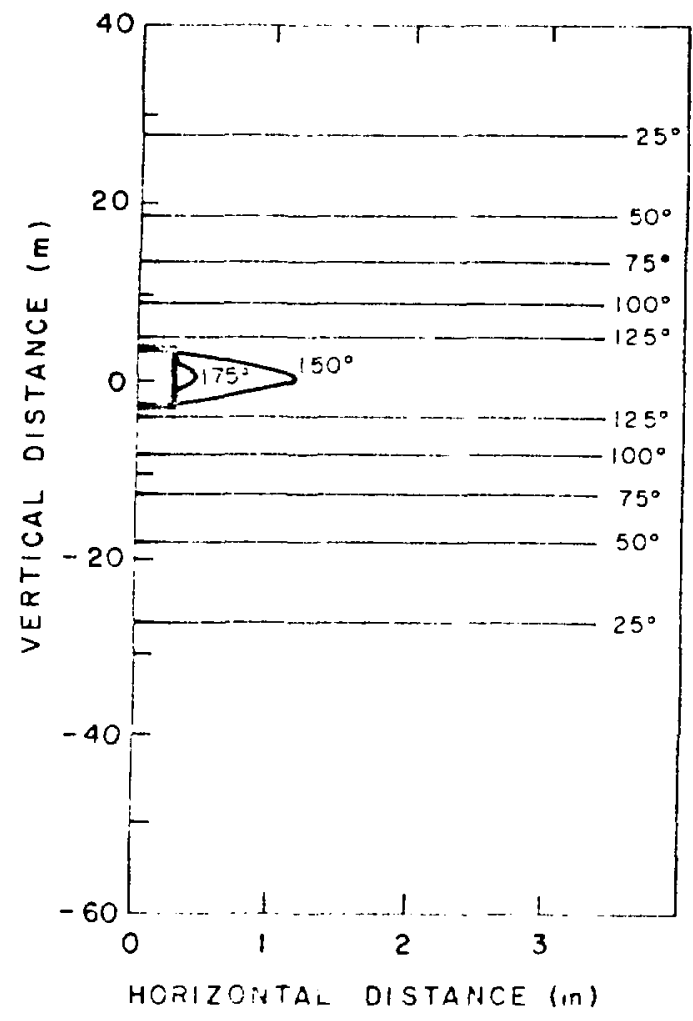

Fig. 6

Thermal Model III. The calculated spacial temperature distribution about a single spent fuel canister at the time of maximum temperature. This case is for ten-year-old spent fuel in a medium of $0.5 \mathrm{~W} / \mathrm{mK}$ conductivity.

appears that unacceptable temperature rises would not occur if conductivity is $1.2 \mathrm{~W} / \mathrm{mK}$. Third, in the more typical alluvium ( $\lambda=0.5$ to $0.8 \mathrm{~W} / \mathrm{mK}$ ) storage of 100-year-old wastes, either high-level or spent fuel, would not cause excessive temperature rises. It should be kept in mind that this calculation is expressly dependent on the waste form and that canisters containing less waste would cause smaller temperature rises than those calculated here. Further, other heat transfer mechanisms may possibly operate in addition to the simple conduction modeled here (Smyth and others, 1978, appendix).

\section{CONCLUSIONS}

Reviewing the required geologic criteria for long term waste isolation and the information on physical properties of alluvium assembled here, it is 
possible to make a preliminary evaluation of the waste isolation potential of alluvium. Alluvium occurs in thicknesses up to $600 \mathrm{~m}$ in topographically closed and open valleys in southern Nevada and possesses no forseeable intrinsic economic value. Although thicknesses may not be as great as other media in the Great Basin (e.g., granite, tuff, and argillite) they may be adequate for long term isolation of wastes. The tectonic and volcanic hazards to waste isolation would have to be evaluated on a site by site basis not within the scope of this report. Alluvium has a high average permeability relative to other media under consideration although a few clay-rich horizons have low permeabilities and may be acceptable. Much alluvium (up to $300 \mathrm{~m}$ ) lies above the water table and all areas considered here lie within the closed Great Basin drainage system with eventual ground water discharge into Death valley and no outlet to the ocean.

The thermal properties investigated here indicate that excessive temperature buildups will not occur in alluvium if either: (1) spent fuel or high-level waste is aged for 100 years before emplacement; (2) a high-conductivity alluvium site is selected; (3) smaller waste packages are prepared; (4) non-heat-producing transuranic wastes only are emplaced; or (5) an active or passive cooling system is used for the first 300 to 500 years. Land areas required for heat dissipation do not appear to exceed what is available, although they are likely to be greater than for any of the other media. Mechanical properties of alluvium do not appear to preclude mining of tunnels and shafts although steel sets may be required in less indurated material. It is likely that mining costs will exceed those of tuff and granite and may be similar to those projected for argiliite. For sorptive properties, the alluvium appears to be approximately equal to the zeolitized tuff and superior to other media under consideration.

In summary, this investigation has not brought to light any failure mechanism by which one could rule out alluvium from consideration as a primary waste isolation medium. However, the alluvium appears to rank behind one or inore other possible media in all properties examined except for sorption properties. It is therefore recommended that alluvium be considered as a secondary medium for containment of heat-producing wastes (i.e., HWL or spent fuel) unless sites in other rock types in the Great Basin are eliminated from consideration on grounds other than those considered here. 


\section{REFERENCES}

1. J. W. Bartlett, J. R. Carrel1, M. R. Krecter, A. M. Platt and J. A. Poweil, editors. "Alternatives for Managing Wastes from Reactors and Post-Fission Operations in the LWR Fuel Cycle," U.S. Energy Research and Development Administration report $476-43$, v. 1, p. 2-33 (1976).

2. E. Blackwelder, "Mudflows as a Geologic Agent in Semi-Arid Mountains," Geo1. Soc. Amer. Bul1., v. 39, p. 465-404 (1928).

3. E. Blissenbach, "Geology of Alluvial Fans in Semiarid Regions," Geol. Soc. Amer. Bu11., v. 65, p. 775-190 (1954).

4. Bonner, E. P., A. E. Abey, H. C. Heard, R. N. Schock, "High Pressure Mechanical Properties of Merl in Alluvium," Lawrence Livermorc Laboratory report UCRL-51252 (1972).

5. G. D. Brunton and W. C. MCClain, "Geologic Criteria for Radioactive Waste Repositories," Union Carbide Corp., Oak Ridge, Tennessee, U.S.A. (1977).

6. W. B. Bull, "Recognition of Alluvial-Fan Deposizs in the Stratigraphic Record," in Recognition of Ancient Sedimentary Environments, Soc. Econ. Paleo. Min. Spec. Pub. T6, 63-83 (1972).

7. S. P. Clark, Jr., "Thermal Conductivity," in Handbook of Physical Constants, S. P. Ciark, Jr., editor, Geol. Sỏ. Amer. Memoir 97, p. 459-482, (1966).

8. S. N. Davis and R. S. M. Dewiest, "Hydrogeology," John Wiley and Sons, Inc., 463 p. (1966).

9. L. S. Denny, "Alluvial Fans in the Death Valley Region, California and Nevada," U.S. Geol. Survey Prof. Paper 466, 62 p. (1965).

10. A. T. Fernald, G. S. Corchary, W. P. Williams, and R. B. Colton, "Surficial Deposits of Yucca Flat Area, Nevada Test Site," in Eckel, E. B., editor,

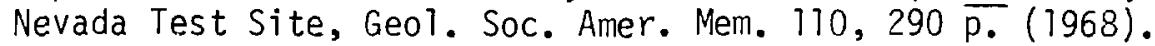

11. W. Flanges, Private communication (1978).

12. Heard, H. C. and D. R. Stephens, "Compressibility and Strength Behavior of Diagonal Line Alluvium," Lawrence Livermore Laboratory report UCID-15736 (1970).

13. E. Hertig, Private communication (1978).

14. D. C. Hoffman, R. Stone, and W. W. Dudley, Jr., "Radioactivity in the Underground Environment of tho Cambric Nuclear Explosion at the Nevada Test Site," Los Alamos Scientific Laboratory Report LA-6877-MS (1977).

15. R. L. B. Hooke, "Processes on Arid-Region Alluvial Fans," Jour. Geol., v. 75 , p. $438-460(1967)$. 
16. R. C. Lincoln, D. W. Larson, C. E. Sisson, "Estimates of Relative Areas for the Disposal in Bedded Salt of LWR Wastes from Alternative Fuel Cycles," SAND771816, Sandia Laboratories, Albuquerque, NM, 1978.

17. L. K. Lustig, "Clastic Sedimentation in Deep Springs Valley, California," U.S. Geo1. Survey Prof. Paper 352-F, p. 131-192 (1965).

18. C. E. Price, and W. Thordarson, "Groundwater Test Well A, Nevada Test Site, Nye County, Nevada, A Summary of Lithologic Data, Aquifer Tests, and Construction," U.S. Geol. Survey TEI-800, Open-File Report, 59 p. (1961).

19. J. R. Smyth, B. M. Crowe, and P. M. Halleck, "An Evaluation of the Storage of Radioactive Wastes Within Silicic Pyroclastic Rocks," submitted to Environmental Geology (1978).

20. Stephens, D. R., H. C. Heard, R. N. Schock; "High Pressure Mechanical Properties of Tuff from the Diamond Dust Site," Lawrence Livermore report UCRL-50858 (1970).

21. W. Thordarson, M. S. Garber, and G. E. Walker, "Ground-water Test Well D, Nevada Test Site, Nye County, Nevada," U.S. Geol. Survey, TEI-803, Open-File Report, 58 p. (1962).

22. T. J. Winograd and W. Thordarson, "Hydrogeologic and Hydrochemical Framework, South-Central Great Basin, Nevada-California, with specizl reference to the Nevada Test Site," U.S. Geol. Survey Prof. Paper 712-C, 126 p. (1975).

23. K. Wolfsberg, "Sorption-Desorption Studies of Nevada Test Site Alluvium and Leaching Studies of Nuclear Test Debris," Los Alamos Scientific Laboratory Report LA-7216-MS (1978).

24. P. I. Yanev and G. N. Owen, "Nevada Test Site Terminal Waste Storage Program: Subtask 1.3. Facility Hardening Studies." Report No. JAB-99-123, National Technical Information Service, U.S. Dept. Commerce, $109 \mathrm{pp.}$ (1978). 